\title{
FAKTOR-FAKTOR YANG MEMENGARUHI KESADARAN MORAL DAN KEMUNAFIKAN
}

\author{
Irfan Fahmi \\ Fakultas Psikologi UIN Sunan Gunung Djati Bandung, Jl. A.H Nasution No. 105 Bandung \\ email: irfan.fahmi@gmail.com
}

\begin{abstract}
Abstrak
Studi literatur mengidentifikasi dua praktik keagamaan yang diduga berpengaruh terhadap kesadaran moral yaitu berdoa sebelum melakukan suatu kegiatan dan berwudhu untuk menjaga kesucian lahiriah. Rancangan eksperimental Faktorial 2x2 digunakan untuk menguji hipotesis. Partisipan sebanyak 103 mahasiswa yang mengikuti mata kuliah tes kecerdasan pada fakultas Psikologi UIN Sunan Gunung Djati Bandung. Hasil menunjukan bahwa berdoa sebelum melakukan kegiatan dan kesucian lahiriah karena berwudhu tidak terbukti mempengaruhi kesadaran moral dan perilaku moral partisipan. Hal ini ditunjukkan oleh perilaku mencontek dan kemunafikan. Salah satu faktor yang secara signifikan terbukti berpengaruh terhadap perilaku moral adalah keyakinan moral.
\end{abstract}

Kata kunci : doa, wudhu, kesadaran moral, dan kemunafikan

\section{Abstract}

Literature study identify two religion practices suspected affecting moral awareness, praying before doing activity and cleansing before praying. Factorial $2 \times 2$ experimental study was used to analyse hypothesis, Participants are 103 students from psychology faculty UIN Sunan Gunung Djati Bandung taking intelegency test class. Result shows that praying before doing activity and cleansing before praying for physical purity are not significantly proven affecting moral awareness and moral behavior since cheating and liar are still occured, one factor which is significantly proven affect moral behavior is moral belief.

Keywords: praying, cleansing before praying, moral awareness, and liar

\section{PENDAHULUAN}

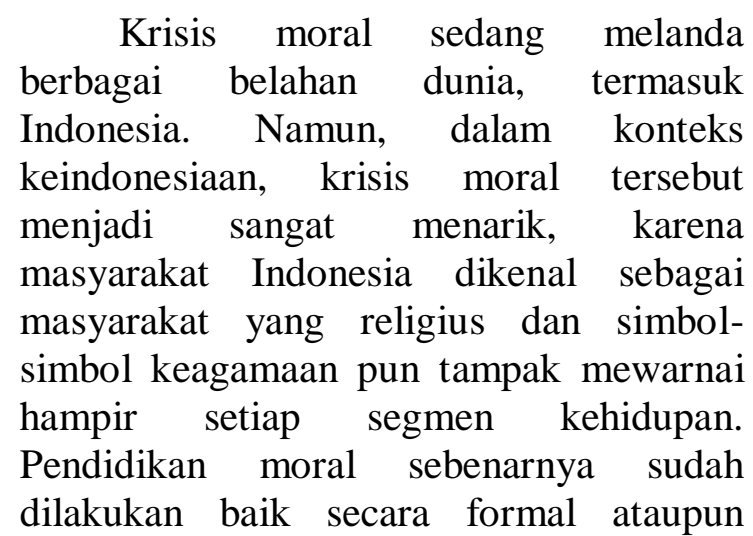

informal. Namun, proses pendidikan moral yang selama ini dilakukan tampaknya belum cukup memadai untuk menciptakan masyarakat yang benar-benar bermoral. Menariknya, pelanggaran nilai-nilai moral sebagiannya justru dilakukan oleh orangorang sangat mengerti nilai-nilai moral, bahkan mengklaim dan mempresentasikan dirinya sebagai orang yang bermoral. Kasus-kasus korupsi, misalnya, ternyata melibatkan orang-orang yang secara sosial dikenal bermoral dan sangat mengerti 
nilai-nilai agama; kekerasan dan seks bebas sebagiannya justru dilakukan oleh mahasiswa atau pelajar yang mengklaim dirinya sebagai kaum terdidik dan bermartabat; pelecehan seksual atau kekerasan sebagiannya justru dilakukan oleh guru agama yang dikenal publik sebagai orang yang bermoral; atau kebohongan publik seringkali dilakukan secara vulgar dan terbuka oleh politisi atau pejabat negara hanya untuk mendapatkan penerimaan publik.

Fenomena tidak menyatunya antara pengetahuan dan perilaku, perkataan dan tindakan, antara apa yang dipresentasikan dan apa yang dilakukan; bukan saja menarik tapi juga penting untuk diteliti. Sebab, konsistensi antara apa yang diyakini dan apa yang dilakukan merupakan ciri utama dari seorang yang bermoral dan paripurna (Blasi, 1983; Damon, 1996) serta merupakan nilai yang sangat mendasar untuk diteliti secara empiris (Collier, 1997).

Dalam psikologi moral, salah satu konstruk psikologis yang berhubungan dengan fenomena tersebut antara lain konstruk kemunafikan (moral hypocrisy). Kemunafikan bisa diartikan sebagai kesenjangan antara pernyataan verbal -baik berupa klaim kepemilikian suatu moralitas atau perintah terhadap orang lain untuk memiliki moralitas tertentu-- dengan apa yang dilakukan yang tujuannya agar mendapatkan kesan bermoral di hadapan orang lain (Batson, Thompson, dan Chen, 2002; Barden, Rucker, dan Petty, 2005; Stone dan Fernandez, 2008; Lammer, Stapel, dan Galinsky, 2010). Penelitian ilmiah mengenai kemunafikan pertama kali dilakukan pada tahun 1991-an oleh Aronson, Fried, dan Stone. Semenjak itu penelitian mengenai kemunafikan yang dipublikasikan di jurnal-jurnal ilmiah tidak kurang dari 32 penelitian.

Di antara penelitian-penelitian tersebut, yang menarik bagi peneliti adalah penelitian Thomas P. Carpenter dan Margaret A. Marshal pada tahun 2009.
Mereka menguji pengaruh religious priming dan intrinsic religious motivation terhadap kemunafikan dengan subjek penelitian siswa-siswa yang beragama Kristen. Hasil penelitian mereka ternyata cukup mengagetkan, yaitu bahwa motivasi keberagamaan intrinsik hanya berpengaruh negatif terhadap kemunafikan hanya apabila di-priming. Jika tidak di-priming, orang yang motivasi keberagamaannya intrinsik pun sangat besar peluangnya untuk munafik atau tidak terintegrasi secara moral.

Penelitian Carpenter dan Marshal mengindikasikan bahwa supaya terhindar dari kemunafikan, diperlukan kesadaran moral yang terus menerus. Penelitian Carpenter dan Marshal sebenarnya mendukung hasil penelitian sebelumnya yang dilakukan oleh Batson, Kobrynowicz, Dinnerstein, Kampf, dan Wilson (1997) yang menyatakan perlunya kesadaran terhadap standar moral untuk menghindari kemunafikan.

Berkaitan dengan kesimpulan tersebut, rendahnya integritas moral masyarakat Indonesia boleh jadi karena pendidikan nilai-nilai keagamaan yang selama ini dilakukan tidak berhasil menumbuhkan kesadaran moral yang terus-menerus. Padahal, agama Islam sebenarnya memiliki syariat yang diduga bisa berfungsi sebagai priming dan dapat menjaga kesadaran moral pemeluknya dari waktu ke waktu sehingga bisa terhindar dari kemunafikan dan memiliki kepribadian yang integrated. Oleh karena itu, peneliti tertarik untuk meneliti praktikpraktik keagamaan yang secara teoritik dan empirik terbukti dapat memelihara kesadaran moral sehingga terhindar dari kemunafikan. Beberapa praktik keagamaan yang umumnya dilakukan oleh umat Islam yakni anjuran untuk berdoa ketika menjalani kegiatan dan ritual berwudhu.

Peneliti bermaksud mengeksplorasi lebih jauh secara teoritik, dan membuktikannya secara empirik bagaimana pengaruhnya terutama ritual 
berdoa dan berwudhu terhadap kesadaran moral dan kemunafikan.

\section{KAJIAN TEORI}

\section{Agama dan Kemunafikan}

Secara sosial ataupun spiritual, perilaku munafik atau kemunafikan merupakan karakter yang tidak disukai. Masyarakat memandang kemunafikan sebagai karakter menjijikan. Penelitian Haidt, Rozin, Mccauley \& Imada, (1997) mengindentifikasi kemunafikan, kebrutalan, dan rasisme sebagai karakter yang menjijikkan. Dalam Islam, kemunafikan merupakan sesuatu yang tidak disukai dan dilarang. Orang yang munafik diancam akan ditempatkan di tempat yang paling rendah nanti di neraka, dan tidak ada seorang pun yang akan memberikan pertolongan kepadanya (QS. An-Nisaa, 4 : 45). Di ayat lain disebutkan bahwa besar kemarahan Allah kepada orang yang mengatakan sesuatu, tapi tidak melakukannya (QS. Ash-Shaff, $61: 2$ ). Kemudian, dijelaskan pula karakteristik orang munafik sebagai orang yang suka menipu dirinya sendiri, apabila melaksanakan shalat lalai, riya atau ingin dilihat oleh orang lain, dan jarang mengingat Allah atau jarang berdzikir (QS. An-Nisaa, 4 : 142). Hadits yang diriwayatkan Bukhori dan Muslim juga menjelaskan tanda-tanda orang munafik, yaitu apabila berkata dusta, apabila berjanji mengingkari, dan apabila dipercayai berhianat (HR. Bukhori dan Muslim).

Kemunafikan dijelaskan sebagai kesenjangan antara keyakinan moral dan perilaku moral yang motivasi moralnya bersifat khas (Batson \& Thompson, 2001). Batson \& Thompson menjelaskan terdapat tiga motivasi moral, yaitu self interest, moral integrity, dan moral hypocrisy. Orang yang motivasinya self interest akan menunjukkan konsistensi antara keyakinan yang dimilikinya dengan apa yang dilakukannya sepanjang perilakunya tersebut menguntungkan kepentingan dirinya; orang yang motivasinya moral integrity menjadikan konsistensi antara keyakinan dan perilakunya sebagai tujuan; sedangkan orang yang motivasinya moral hypocrisy di satu sisi berusaha menunjukkan dirinya tampak bermoral, tapi di lain sisi tidak mau mengambil resiko untuk berperilaku sesuai dengan apa yang ditampakkannya.

Menurut Monin dan Merrit (2010) terdapat empat kategori ketika menjelaskan hubungan antara kemunafikan dan inkonsistensi perilaku

\begin{tabular}{|c|c|c|}
\hline & $\begin{array}{c}\text { Tidak Ada } \\
\text { Inkonsistensi } \\
\text { Perilaku }\end{array}$ & $\begin{array}{c}\text { Ada } \\
\text { Inkonsistensi } \\
\text { Perilaku }\end{array}$ \\
\hline $\begin{array}{c}\text { Tidak Ada } \\
\text { Kemunafikan }\end{array}$ & Moral Integrity & Weakness of Will \\
\hline $\begin{array}{c}\text { Ada } \\
\text { Kemunafikan }\end{array}$ & Bad Faith & $\begin{array}{l}\text { Not Practicing } \\
\text { What One } \\
\text { Preaches }\end{array}$ \\
\hline
\end{tabular}

Tabel 2.1. Peta Hubungan antara Kemunafikan dan Inkonsistensi Perilaku (Monim dan Merrit, 2010)

\section{Agama dan Regulasi Perilaku}

Sejarah mencatat bahwa agama merupakan suatu pranata sosial yang cukup kontroversial. Di satu sisi, agama kadang dituding sebagai candu masyarakat, sumber fundamentalisme dan radikalisme, tukang teror, serta jauh dari rasionalisme seperti yang dijunjung tinggi oleh kebanyakan masyarakat modern. Tapi, di lain sisi agama seringkali diklaim sebagai salah satu faktor yang dapat mendorong munculnya perilaku-perilaku positif, menjauhkan masyarakat dari perilaku bermasalah, dan berpengaruh positif terhadap kesehatan mental serta kebahagiaan hidup masyarakat.

McCullough dan Willoughby (2009) menyimpulkan beberapa hal : agama dapat mempromosikan 
pengendalian diri atau self control; agama berperngaruh pada pemilihan, pencapaian dan pengaturan suatu tujuan; agama dapat memfasilitasi self monitoring; Agama dapat meningkatkan perkembangan self-regulation strength; agama dapat mengatur dan mendorong kemampuan behavioral self-regulation; beberapa pengaruh agama terhadap kesehatan, well being, dan perilaku sosial sebagai akibat dari pengaruh agama terhadap self-control dan selfregulation.

Kesimpulan McCullough dan Willoughby (2009) dan McCullough dan Carter (2011) tampak bahwa agama berpengaruh positif terhadap self regulation. Yang dimaksud self regulation, menurut Hofmann, Friese, \& Strack (2009); Reynolds, Penfold, \& Patak, (2008), menunjuk pada suatu upaya untuk mengendalikan pikiran, perasaan, dan perilaku dalam rangka mencapai suatu tujuan. Selain itu, penelitian McCullough dan Willoughby (2009) dan McCullough dan Carter (2011) pun menyimpulkan bahwa terdapat banyak ritual keagamaan yang mengajarkan behavioral self regulation (BSR), yaitu aspek perilaku dari konstruks self regulation

\section{Regulasi Perilaku dan Kesadaran Moral}

Penelitian Bryant (2009)
menyatakan bahwa orang yang
memiliki karakteristik pengendalian diri
yang kuat secara moral ternyata lebih
sadar dan karakteristik itu berpengaruh
pada penalaran moral, sebaliknya orang
yang memiliki karateristik pengendalian
diri yang rendah juga memiliki
kesadaran moral yang rendah pula.
Ada beberapa definisi mengenai
kesadaran moral (moral awareness).
Rest (1986) berpendapat bahwa
kesadaran moral merupakan proses
interpretif dimana individu mengenali
bahwa terdapat suatu masalah moral

pada situasi tertentu atau bahwa suatu standar/prinsip moral relevan dengan suatu situasi tertentu. Definisi lain yang lebih detil disampaikan oleh Butterfield,Trevino, dan Weaver (2000). Menurut mereka, kesadaran moral adalah pengenalan seseorang bahwa keputusan ataupun tindakannya akan berpengaruh pada kepentingan, kesejahteraan, atau harapan dirinya ataupun orang lain yang mungkin bertentangan dengan satu atau beberapa standar moral.

Kesadaran moral ini memiliki peran yang sangat penting dalam pembentukan suatu perilaku moral. Rest (1986) menyebutkan bahwa kesadaran moral mendasari penalaran moral dan pengambilan keputusan yang berhubungan dengan moral. Tanpa kesadaran moral, siapapun tidak mungkin melakukan pertimbangan moral dan kemudian mengambil suatu keputusan moral (Bryant, 2009). Penelitian Bryant menunjukkan bahwa kesadaran ini akan membuat orang menjaga integritas pribadinya dan berusaha membangun kepercayaan interpersonal.

Dari apa yang disampaikan oleh Rest, Bryant, Jones dan Ryan tampak bahwa kesadaran moral merupakan tahapan awal yang sangat penting untuk memungkinkan seseorang melakukan suatu penalaran moral dan perilaku moral. Dan kesadaran moral ini bisa ditingkatkan dengan desain pendidikan ataupun teknik pelatihan yang dapat meningkatkan karakteristik pengendalian diri (Bryant, 2009).

\section{METODOLOGI PENELITIAN}

\section{Desain Penelitian}

Penelitian ini termasuk penelitian eksperimen dengan rancangan Factorial Design $2 \times 2$ unrelated sample atau $2 \times$ 2 between-subject, yaitu rancangan penelitian eksperimental dengan dua variabel independen dengan sampel 
yang berbeda untuk masing-masing kondisi (Harris, 2002).

Tabel 3.1 Desain Faktorial 2 x 2 Unrelated sample

\begin{tabular}{|c|c|}
\hline $\begin{array}{c}\text { Kelompok I } \\
\text { Berwudhu dan Berdoa }\end{array}$ & $\begin{array}{c}\text { Kelompok II } \\
\text { Berwudhu }\end{array}$ \\
\hline $\begin{array}{c}\text { Kelompok III } \\
\text { Berdoa }\end{array}$ & $\begin{array}{c}\text { Kelompok IV } \\
\text { Tidak Mendapatkan Perlakuan }\end{array}$ \\
\hline
\end{tabular}

\section{Sumber Data/Informasi}

Penelitian dilakukan pada mahasiswa Fakultas Psikologi UIN SGD Bandung. Sampel yang digunakan adalah mahasiswa Fakultas Psikologi UIN SGD Bandung yang mengambil mata kuliah Tes Kecerdasan berjumlah 103 orang.

\section{Variabel Penelitian}

Variabel yang terlibat dalam penelitian ini adalah :

1. Doa

2. Wudhu

3. Perilaku menyontek

4. Kemunafikan

Selain variabel-variabel tersebut, dalam manipulation check, peneliti mengidentifikasi mengenai kesadaran moral dan keyakinan moral partisipan penelitian.

\section{Teknik Pengumpulan Data}

Pengumpulan data dilakukan
secara langsung menggunakan
eksperimen dengan desain factorial
design dan menggunakan skala
menyontek untuk memperoleh data
mengenai perilaku moral yang dalam
penelitian ini berupa perilaku
menyontek.

\section{Pengolahan dan Analisis Data}

Analisis data menggunakan beberapa uji statistik. Untuk mengetahui sejauhmana manipulasi eksperimental bekerja seperti yang diharapkan, peneliti menggunakan uji Chi-square; untuk mengetahui pengaruh variabel Doa dan Wudhu terhadap Perilaku
Mencontek, peneliti menggunakan Faktorial Anova; untuk mengetahui pengaruh variabel Doa dan Wudhu terhadap Kemunafikan, peneliti menggunakan Loglinier Regression; dan untuk mengetahu pengaruh Kesadaran Moral dan Keyakinan Moral terhadap Perilaku Mencontek, peneliti menggunakan Analisis Regresi Majemuk.

\section{HASIL PENELITIAN}

\section{Analisis pendahuluan}

a. Perbedaan persepsi mengenai kesucian lahiriah antara kelompok 1, 2, 3, dan 4

Uji $F$ menunjukkan bahwa tidak terdapat perbedaan persepsi mengenai kesucian lahiriah antara kelompok 1, 2, 3, dan 4 (F (3) = 1,586, $p=0,198$. Analisis kontras antara kelompok 3 dengan $4(\mathrm{t}(50)=$ - 1,582, $p=0,120$ ) dan kelompok 1 dengan $4(\mathrm{t}(47)=-1,828, \mathrm{p}=$ 0,074), juga menunjukkan bahwa antara kelompok-kelompok tersebut tidak terdapat perbedaan persepsi mengenai kesucian lahiriahnya. Hal ini menunjukkan bahwa manipulasi eksperimen tidak berjalan seperti yang diharapkan.

b. Perbedaan kesadaran moral antara kelompok 1, 2, 3, dan 4

Uji $F$ menunjukkan bahwa tidak terdapat perbedaan kesadaran moral antara kelompok 1, 2, 3, dan 4 $(\mathrm{F}(3)=0,266, p=0,849)$. Analisis kontras antara kelompok 2 dengan 4 $(\mathrm{t}(45)=0,659, \mathrm{p}=0,513)$ dan kelompok 1 dengan $4(\mathrm{t}(47)=$ $0,110, p=0,913)$, juga menunjukkan bahwa antara kelompok-kelompok tersebut tidak terdapat perbedaan persepsi mengenai kesucian lahiriahnya. Hal ini menunjukkan bahwa manipulasi eksperimen tidak berjalan seperti yang diharapkan.

1. Analisis Utama 
a. Pengaruh doa dan wudhu terhadap kesadaran moral

Uji Faktorial Analisis Varian menunjukkan bahwa faktor doa dan wudhu tidak berpengaruh terhadap kesadaran moral. Hal itu ditunjukkan dengan nilai $F(3)=0,051$, dengan $p$ $=0,984$.

b. Pengaruh doa dan wudhu terhadap perilaku mencontek

Uji Faktorial Analisis Varian menunjukkan bahwa tidak terdapat pengaruh doa dan wudhu terhadap perilaku mencontek. Hal itu ditunjukkan dengan nilai $\mathrm{F}(3)=$ 0,712 , dengan $p=0,552$. Namun, pengaruh tersebut lebih banyak dipengaruhi oleh kontribusi Keyakinan Moral $(\beta 1=-0,378)$, daripada Kesadaran Moral $((\beta 1=-$ 0,073). Uji t menunjukkan bahwa Kesadaran Moral $(\mathrm{t}=-0,694$ dengan nilai $\mathrm{p}=0,489$ ). secara statistik tampak tidak signifikan dibanding dengan Keyakinan Moral $(t=-3,615$ dengan nilai $p=0,000)$.

c. Pengaruh Doa dan Wudhu terhadap Kemunafikan

Analisis

Loglinier menunjukkan bahwa doa dan wudhu tidak berpengaruh pada kemunafikan. Hal itu ditunjukkan dengan nilai $\chi^{2}(3)=1,588, p=$ 0,662 .

2. Analisis Tambahan

a. Kategori Kesadaran Moral

Analisis deskriptif menunjukkan mean empirik perilaku mencontek partisipan penelitian sebesar 7,84. Karena mean empirik lebih besar daripada mean hipotetiknya $(4,5)$, maka kesadaran moral partisipan penelitian bisa disimpulkan termasuk di atas ratarata.

Perbandingan antara mean hipotetik $(4,5)$ dan mean empirik $(7,84)$ menunjukkan bahwa kesadaran moral partisipan penelitian termasuk di atas rata-rata.

b. Kategori Keyakinan Moral

Analisis deskriptif menunjukkan mean empirik perilaku mencontek partisipan penelitian sebesar 7,35. Karena mean empirik lebih besar daripada mean hipotetiknya $(4,5)$, maka keyakinan moral partisipan penelitian bisa disimpulkan termasuk di atas ratarata.

c. Kategori Perilaku Mencontek

Analisis deskriptif menunjukkan mean empirik perilaku mencontek partisipan penelitian sebesar 17,36. Karena mean empirik lebih kecil daripada mean hipotetiknya (25), maka perilaku mencontek partisipan penelitian bisa disimpulkan termasuk di bawah ratarata.

\section{PEMBAHASAN}

Hasil penelitian menunjukkan bahwa hipotesis peneliti sebagian besarnya tidak diterima (hipotesis nol-nya diterima). Berdoa sebelum melakukan suatu kegiatan, yang secara teoritis diduga dapat meningkatkan kesadaran moral sehingga dapat menurunkan perilaku mencontek dan kemunafikan ternyata tidak terbukti secara empirik. Demikian juga dengan faktor kesucian tubuh. Wudhu yang secara teoritik diduga akan meningkatkan kesadaran moral sehingga dapat menurunkan perilaku mencontek dan kemunafikan ternyata tidak terbukti secara empirik.

Secara teoritik, berdoa diduga dapat meningkatkan kesadaran moral. Berdoa dapat membuat seseorang menyadari nilainilai yang diyakininya, dan akan lebih peka terhadap inkonsistensi antara keyakinan moral dan perilaku moralnya. Inkonsistensi merupakan suatu kondisi yang tidak menyenangkan dan bisa menimbulkan dissonansi kognitif (Cognitive Dissonance) serta perasaan 
bersalah (Guilty). Karena inkonsistensi dapat menimbulkan dissonansi kognitif dan perasaan bersalah, makan orang yang berdoa akan cenderung menjauhkan diri dari pelanggaran moral. Sama halnya dengan berdoa, berwudhu pun secara teoritik diduga dapat meningkatkan kesadaran moral. Penelitian sebelumnya menunjukkan bahwa kesucian lahiriah akan berasosiasi dengan perilaku-perilaku yang suci juga. Karena perilaku mencontek dan kemunafikan merupakan perilaku yang melanggar prinsip kesucian, maka orang yang berwudhu akan cenderung menghindari perilaku mencontek dan kemunafikan.

Hipotesis peneliti bahwa Kesadaran Moral dapat berpengaruh terhadap perilaku moral - perilaku mencontek dan kemunafikan - ternyata tidak terbukti secara empirik. Berbeda dengan Kesadaran Moral, hipotesis peneliti mengenai pengaruh Keyakinan Moral terhadap perilaku Moral terbukti secara empirik. Hal itu sesuai dengan penelitian-penelitian sebelumnya yang menunjukkan bahwa keyakinan moral (moral beliefs) merupakan prediktor perilaku yang sangat menyakinkan di banding prediktorprediktor lain seperti penalaran moral, emosi moral, identitas moral (Schroeder, Roskies, \& Nichols, 2010).

Terdapat beberapa argumen yang dapat menjelaskan mengapa hal beberapa hipotesis nol diterima dan hipotesis penelitian ditolak. Pertama, faktor yang paling berpengaruh terhadap ditolaknya hipotesis peneliti adalah manipulasi eksperimental yang dilakukan tidak berjalan sesuai dengan yang diinginkan. Manipulasi berdoa sebelum mengikuti ujian tidak membuat kelompok eksperimen dan kelompok kontrol berbeda dalam hal kesadaran moralnya. Manipulasi berwudhu sebelum mengikuti ujian pun tidak membuat kelompok eksperimen dan kelompok kontrol berbeda dalam hal persepsi mengenai kesucian lahiriahnya serta kesadaran moralnya.
Faktor kedua yang menyebabkan ditolaknya hipotesis peneliti adalah faktor jumlah partisipan penelitian. Uji signifikan dengan melihat nilai alpha sangat bergantung pada jumlah partisipan, semakin banyak partisipan penelitian maka probabilitas untuk mendapat nilai alpha yang signifikan semakin besar. Sebenarnya, sebelumnya proses eksperimen hal tersebut disadari betul oleh peneliti, namun karena penelitian eksperimen seringkali kesulitan jika menggunakan subjek penelitian yang besar.

Faktor ketiga, terdapat banyak faktor yang berpengaruh terhadap perilaku moral. Kesadaran moral hanyalah salah satu faktor yang diduga berpengaruh terhadap perilaku moral. Faktor yang lainnya adalah penalaran moral, identitas moral, emosi moral, keyakinan moral, dan lain-lain. Dengan demikian, boleh jadi hasil penelitian tersebut menunjukkan hasil yang sebenarnya, yaitu bahwa kesadaran moral kurang berpengaruh terhadap perilaku moral.

\section{KESIMPULAN}

Penelitian ini menyimpulkan bahwa berdoa sebelum melakukan suatu kegiatan dan kesucian lahiriah melalui wudhu tidak terbukti secara signifikan berpengaruh pada kesadaran moral dan perilaku moral (perilaku mencontek dan kemunafikan). Selain itu, kesadaran moral pun tidak terbukti secara signifikan berpengaruh perilaku moral. Salah satu faktor yang cukup menyakinkan pengaruhnya terhadap perilaku moral keyakinan moral. Orang meyakini nilai-nilai moral terbukti menunjukkan perilaku moral yang konsisten dengan perilaku moralnya.

\section{SARAN}

1. Hasil penelitian ini sebaiknya diinterpretasikan dengan hati-hati. Ada beberapa alasan mengapa hal tersebut harus dilakukan. Pertama, penelitian ini menggunakan partisipan yang tidak 
terlalu banyak. Padahal uji signifikasi sebagai tolak ukur diterima/ditolaknya hipotesis penelitian sangat dipengaruhi oleh jumlah partisipan. Kedua, prosedur penelitan ini tidak secara ketat mengontrol variabel-variabel lain yang berpengaruh pada variabel-variabel penelitian.

2. Pendidikan moral sebaiknya tidak sebatas pada peningkatan penalaran moral semata atau pembiasaan perilaku simbolik keagamaan tanpa penghayatan terhadap apa-apa yang dilakukan. Yang lebih penting adalah pendidikan moral sebaiknya berusaha menanamkan keyakinan moral secara mendalam, dan memfasilitasi penghayatan terhadap perilaku simbolik keagamaan yang dilakukan dengan baik.

\section{DAFTAR PUSTAKA}

Al Ghazali (1998). Menjelang Hidayah : Mukadimah Ihya Ulumuddin. (Penj. As'ad El-Hafidy). Bandung. Penerbit Mizan.

(2008). Menguak Rahasia Qolbu (Mukasyafatul Qulub). (Penj. Aahrun Abubakar). Bandung. Nuansa Aulia.

Asai, Tomohisa dan Tanno, Yoshiki (2007). The relationship between the sense of self-agency and schizotypal personality traits. Journal of Motor Behavior. Vol 39(3), May 2007, 162168

Barden, J., Rucker, D.D., dan Petty, R.E. (2005). "Saying one thing and doing another": Examining the impact of event order on hypocrisy judgments of others. Personality and Social Psychology Bulletin, 31, 1463-1474.

Batson C.D., Thompson E.R, Seuferling G., Whitney H., \& Strongman J.A (1999). Moral Hypocrisy: Appearing Moral to Oneself Without Being So. Journal of Personality and Social Psychology, 77.

Batson, C. D., Thompson, E. R., \& Chen, H. (2002) Moral hypocrisy:
Addressing some alternatives. Journal of Personality and Social Psychology, 88, 330-339.

Batson, C.D. \& Thompson, E.R. (2001). Why don't moral people act morally? Motivational considerations. Current Directions in Psychological Science, 10 (2), 54-57.

Butterfield, K.D., Treviño, L.K., \& Weaver, G.R. (2000). Moral Awareness in Business Organizations: Influences of IssueRelated and Social Context Factors. Human Relations, 53, 981-1018.

Damasio, A.R (1996). The somatic marker hypothesis and the possible functions of the prefrontal cortex. Philosophical Transactions: Biological Sciences, 351, No. 1346,

Gallagher, S. (2000). Philosophical conception of the self : implication for cognitive science. Trend in Cognitive Sciences. 4, 14-21

Halstead, J.M. (2007) Islamic values: a distinctive framework for moral education? Journal of Moral Education Vol. 36, No. 3, September 2007, pp. 283-296

Hawwa, Said (1998). Mensucikan Jiwa : Konsep Tajkiyatun Nafs Terpadu. Rabbani Press

Jeannerod, M. (2003). The mechanism of self-recognition in humans. Behavioural Brain Research. 142 (2003) 1-15

Kuiper, Nicholas A \& Borowicz-Sibenik, Melanie (2005) A good sense_of humor doesn't always help: Agency and communion as moderators of psychological well-being. Personality and Individual Differences. Vol 38(2), Jan 2005, 365-377

Kunzman, R. (2003). Religion, Ethic and the Implication for Moral Education : a critique of Nucci's Morality and Religious Rules. Journal of Moral Education, 32 (3) 
Lapsley, D.K. (2006). Moral Stage Theory. In Klillen, M. and Smetana, J.G. (Ed.). Handbook of Moral Development. New Jersey London. Lawrence Erlbaum Associates, Publishers

Laurence R., dan Tancredi L. R (2005). Hardwired Behavior : What Neuroscience Reveals about Morality. Cambridge University Press.

Martin, C.S., Earleywine, M., Blackson, T.C., et al., (1994). Aggressivity, inattention, hyperactivity, and impulsivity in boys at high and low risk for substance abuse. Journal Abnormal. Child Psychology, 22, 177-203

McCullough, M.E. dan Willoughby, B.L.B. (2009). Religion, SelfRegulation, and Self-Control: Associations, Explanations, and Implications. Psychological Bulletin, 135(1), 69-93

Miller, J.G. (2007). Cultural Psychology of Moral Development. In Kitayama, S. \& Cohen, D. (Ed.). Handbook of Cultural Psychology. New York. London. The Guilford Press

Naso, R.C (2006). Immoral Actions In Othersiwe Moral Individuals : Interrogating the Structure and Meaning of Moral Hypocrisy. Psychoanalytic Psychology 2006, Vol. 23, No. 3, 475-489

Reynolds, S.J. (2006). Moral Awareness and Ethical Predispositions : Investigating the Role of Individual Differences in the Recognition of Moral Issues. Journal of Applied Psychology, 91(1), 233-243

Smetana, J.G (2006). Social-Cognitive Domain Theory : Consistencies and Variations in Children's Moral and Social Judgments. In Klillen, M. and Smetana, J.G. (Ed.). Handbook of Moral Development. New Jersey London. Lawrence Erlbaum Associates, Publishers.
Tober, D.M. dan Budiani D. (2007). Introduction: Why Islam, Health and the Body? Body \& Society. SAGE Publications, 13 (3), 1-13

Tong, E.M.W. dan Yang, Z., (2011). Moral Hypocrisy: Of Proud and Grateful People. Social Psychological and Personality Science, 2 (2) 159-165.

Turiel, E. (2006). Thought, Emotions, and Social Interactional Processes in Moral Development. In Klillen, M. and Smetana, J.G. (Ed.). Handbook of Moral Development. New Jersey London. Lawrence Erlbaum Associates, Publishers.

Turiel, E. (2008). Thought about actions in social domains: Morality, social conventions, and social interactions. Cognitive Development. 23 (2008) 136-154

Walker, L.J. (2006). Gender and Morality. In Klillen, M. and Smetana, J.G. (Ed.). Handbook of Moral Development. New Jersey London. Lawrence Erlbaum Associates, Publishers.

Watson, G.W. \& Sheikh, F. (2007) Normative Self-Interest or Moral Hypocrisy?: The Importance of Context. Journal of Business Ethics (2008) 77:259-269

Zimmerman, B.J. (2000). Attaining SelfRegulation : A Social Cognitive Perspektive. In Boekarts, M. Pintrich, P.R dan Zeidner, M. (Eds). Handbook of Self Regulation. Academic Press. 